\title{
Plantar fascia evaluation with a dedicated magnetic resonance scanner in weight-bearing position: our experience in patients with plantar fasciitis and in healthy volunteers
}

\section{Valutazione della fascia plantare con risonanza magnetica dedicata in posizione ortostatica: nostra esperienza in pazienti con fascite plantare ed in volontari sani}

\author{
R. Sutera • A. Iovane • F. Sorrentino • F. Candela • V. Mularo • G. La Tona • M. Midiri \\ DIBIMEL, Sezione di Scienze Radiologiche, Università degli Studi di Palermo, Via del Vespro 127, 90127 Palermo, Italy \\ Correspondence to: R. Sutera, Via Francesco Maria Alias 6, 90145 Palermo, Italy, Tel.: +39-091-9295946, Fax: +39-091-6552337, \\ e-mail: raffaello.sutera@alice.it
}

Received: 11 May 2009 / Accepted: 17 September 2009

(C) Springer-Verlag 2010

\begin{abstract}
Purpose. This study assessed the usefulness of upright weight-bearing examination of the ankle/hind foot performed with a dedicated magnetic resonance (MR) imaging scanner in the evaluation of the plantar fascia in healthy volunteers and in patients with clinical evidence of plantar fasciitis.

Materials and methods. Between January and March 2009, 20 patients with clinical evidence of plantar fasciitis (group A) and a similar number of healthy volunteers (group B) underwent MR imaging of the ankle/hind foot in the upright weight-bearing and conventional supine position. A 0.25-Tesla MR scanner (G-Scan, Esaote SpA, Genoa, Italy) was used with a dedicated receiving coil for the ankle/hind foot. Three radiologists, blinded to patients' history and clinical findings, assessed in consensus morphological and dimensional changes and signal intensity alterations on images acquired in both positions, in different sequences and in different planes.

Results. In group A, MR imaging confirmed the diagnosis in $15 / 20$ cases; in $4 / 15$ cases, a partial tear of the plantar fascia was identified in the upright weight-bearing position alone. In the remaining 5/20 cases in group A and in all cases in group B, the plantar fascia showed no abnormal signal intensity. Because of the increased stretching of the plantar fascia, in all cases in group A and B, thickness in the proximal third was significantly reduced $(p<0.0001)$ under upright weight-bearing compared with the supine position.
\end{abstract}

\begin{abstract}
Riassunto
Obiettivo. Scopo del nostro lavoro è stato dimostrare l'utilità dell'esame sotto carico del retropiede/caviglia eseguito con apparecchiatura di risonanza magnetica (RM) dedicata finalizzato alla valutazione della fascia plantare in volontari sani ed in pazienti con evidenza clinica di fascite plantare.
\end{abstract}

Materiali e metodi. Nel periodo compreso tra gennaio e marzo 2009, 20 pazienti con diagnosi clinica di fascite plantare (gruppo A) ed altrettanti volontari sani (gruppo $B)$, sono stati sottoposti ad esame RM del retropiede/caviglia sia in ortostatismo che in clinostatismo. Per le indagini è stata utilizzata una apparecchiatura RM dedicata da 0,25 Tesla (G-Scan, Esaote SpA, Genova, Italia) con bobina di ricezione dedicata per retropiede/caviglia. Tre radiologi in consenso e in cieco sull'anamnesi e l'obiettività clinica dei soggetti hanno valutato le alterazioni morfo-dimensionali e dell'intensità di segnale nelle immagini acquisite nelle due posizioni, nelle diverse sequenze e nei differenti piani di scansione.

Risultati. Nel gruppo A, la RM ha confermato la diagnosi in 15/20 casi; in 4/15 casi è stata evidenziata una rottura parziale della fascia plantare visualizzata solo nella posizione ortostatica. Nei restanti 5/20 casi del gruppo A ed in quelli del gruppo $B$ la fascia plantare non presentava alterazioni dell'intensità di segnale. A causa della maggiore tensione della fascia plantare in tutti i casi, gruppo A e B, lo spessore del tratto peri-inserzionale sotto 
Conclusions. Imaging the ankle/hind foot in the upright weight-bearing position with a dedicated MR scanner and a dedicated coil might enable the identification of partial tears of the plantar fascia, which could be overlooked in the supine position.

Keywords Plantar fascia $\cdot$ MRI $\cdot$ Weight-bearing carico si riduceva significativamente $(p<0,0001)$ rispetto al clinostatismo.

Conclusioni. L'imaging del retropiede/caviglia nella posizione ortostatica con RM dedicata e bobina dedicata potrebbe consentire di dimostrare le rotture parziali della fascia plantare che possono rimanere misconosciute in clinostatismo.

Parole chiave Fascia plantare $\cdot R M \cdot$ Sotto carico

\section{Introduction}

The plantar fascia is the thick, central portion of the plantar aponeurosis that arises from the medial calcaneal tuberosity [1] and inserts distally into the plantar plates of the metatarsal-phalangeal joints. Thanks to its combined static and dynamic role in supporting the longitudinal arch of the foot and its weight-bearing capabilities in the upright position, it is often subject to acute partial or complete tear or traction microtrauma due to functional overload (plantar fasciitis) [2]. Plantar fasciitis is the most common cause of hind-foot pain in long-distance runners. Onset is gradual, with the pain increasing during sporting activity and decreasing with rest. The condition consists of an inflammatory process involving both the fascial fibres and the perifascial structures. Repetitive trauma can also produce microtears of some fibres of the plantar aponeurosis, especially those closest to the calcaneal insertion [3]. A thorough clinical examination based on precise manoeuvres usually provides correct diagnostic orientation [4]. In the setting of diagnostic imaging, both ultrasonography (US) and magnetic resonance (MR) imaging have high levels of accuracy in identifying alterations to the plantar fascia [5-11]. The intrinsic technical and methodological characteristics of MR imaging (multiplanar acquisitions, highcontrast resolution, absence of bone artefacts) generally allow optimisation of the scans in relation to the topography and morphology of the plantar fascia, such that the technique provides invaluable information. In addition, technological development of MR imaging in recent years has seen the introduction of systems with increasingly higher magnetic fields (1.5 and 3 Tesla) and of dedicated devices able to study joints even with the patient in the upright, weight-bearing position. This has opened up new diagnostic possibilities, including the study of the plantar fascia under physiological load, for which no studies are available in the literature.

Our aim was to evaluate information provided by MR study with a dedicated system on the plantar fascia during weight bearing in patients with a clinical diagnosis of plantar fasciitis and in healthy volunteers.

\section{Introduzione}

La fascia plantare è la porzione centrale, più spessa, dell'aponeurosi plantare, ed origina dalla tuberosità calcaneare mediale [1] e si inserisce distalmente sulle placche plantari delle articolazioni metatarso-falangee. Grazie al suo ruolo combinato sia statico che dinamico nel supporto dell'arco longitudinale del piede ed alla capacità di permettere il carico sul piede in ortostatismo, sono frequentemente riscontrabili patologie secondarie a microtraumatismi trazionali che derivano dal sovraccarico funzionale (fascite plantare) o a rottura acuta parziale o completa [2]. La fascite plantare è la causa più comune di dolore al retropiede negli atleti dediti alle marce prolungate ed insorge in modo graduale, aumentando durante l'attività sportiva e regredendo con il riposo; essa consiste in un processo flogistico che coinvolge sia le fibre fasciali che le strutture perifasciali. I traumi ripetitivi possono produrre, inoltre, microlesioni di alcune fibre dell'aponeurosi plantare, in particolare quelle più vicine al sito di inserzione [3]. Un accurato esame clinico, basato su precise manovre semeiologiche, fornisce, di norma, il corretto orientamento diagnostico [4]. Nell'ambito delle tecniche di diagnostica per immagini, sia l'ecografia (US) che la risonanza magnetica (RM) sono accreditate di elevata accuratezza diagnostica nell'identificazione delle alterazioni della fascia plantare [5-11]. Le caratteristiche tecnico-metodologiche intrinseche della RM (acquisizione multiplanare, elevata risoluzione di contrasto, assenza di artefatti ossei), permettono, in genere, di ottimizzare le scansioni in rapporto alla topografia ed alla morfologia della fascia plantare, rendendo insostituibile l'apporto informativo offerto da tale tecnica. Lo sviluppo tecnologico in RM, inoltre, ha portato negli ultimi anni, da un lato, alla messa in commercio di macchine ad intensità di campo sempre più elevato (1,5 e 3 Tesla) e dall'altro, di macchine dedicate con possibilità di studiare le articolazioni anche in ortostatismo, sotto carico gravitazionale, aprendo nuove possibilità diagnostiche, tra cui lo studio della fascia plantare sotto carico fisiologico, di cui non esiste, a tutt'oggi, nessun riferimento nella letteratura scientifica.

Lo scopo del nostro lavoro è quello di valutare le informazioni fornite sulla fascia plantare dalla valutazione RM 


\section{Materials and methods}

Between January and March 2009, two groups of 20 individuals underwent MR imaging with a dedicated system to evaluate the role of acquisitions performed in the upright weight-bearing position. The first group (A) consisted of patients with a clinical diagnosis of plantar fasciitis and the second group (B) of healthy volunteers. No individuals in either group had a history of degenerative, traumatic, neoplastic or infectious foot disease or systemic disease (seronegative spondyloarthropathy, gout, rheumatoid arthritis, psoriatic arthritis, Reiter syndrome, etc.). In addition, patients (group A) had undergone no minimally invasive locoregional procedures, such as shockwave therapy or cortisone injections, but only conservative treatment with oral nonsteroid anti-inflammatory drugs. The mean age in group A (16 men and four women) was 36 (range 24-45) years, and in group B (14 men and six women) it was 33 (range 20-41) years.

All individuals underwent an MR study with a dedicated 0.25-T system (G-Scan, Esaote SpA, Genoa, Italy) in the conventional supine or supine position and in the upright weight-bearing position. The study in the latter position was done with the gantry rotated to approximately $82^{\circ}$ rather than $90^{\circ}$ to allow evaluations under almost complete weight-bearing without inducing a sensation of instability. A dedicated platform-shaped receiver coil was used (Fig. 1), and the foot was securely strapped to the platform to minimise differences in position, thus obtaining practically the same scout image in both the upright and supine positions and therefore approximately equivalent planes. The study was first performed in the weight-bearing position and then completed with the same sequences in the supine position to minimise patient discomfort and avoid onset of orthostatic hypotension and possible motion artefacts. The following sequences were acquired: T1-weighted spin echo (SE) (TR/TE 800/26 ms), T2-weighted turbo spin echo (TSE) (TR/TE 2,860/90 ms), short-tau inversion recovery (STIR) (TR/TE/TI 4,140/30/80 ms) and T1-weighted 3D steady-state free precession (SSFP) (TR/TE 30/15 ms). Characteristics of the T1-weighted SE sequence were a TR $800 \mathrm{~ms}$, which in musculoskeletal MR imaging guarantees optimal contrast (with respect to a particularly short TR) between the tissues involved in the study. In all cases, all sequences were acquired in the sagittal plane, whereas only T2-weighted TSE and STIR sequences were acquired in the coronal plane. A field of view (FOV) of $16 \mathrm{~cm}$ centred on the sole of the foot was used for all the sequences. With the exception of the volumetric T1-weighted 3D-SSFP sequences (for which an acquisition matrix of $224 \times 224$ was used), all sequences were characterised in acquisition by a number of samples in the read direction and a number of phase encodings in the phase-encoding directions $>256$. sotto carico eseguita con apparecchiatura dedicata nei pazienti con diagnosi clinica di fascite plantare e nei volontari sani.

\section{Materiali e metodi}

Nel periodo compreso tra gennaio e marzo 2009, al fine di valutare il ruolo delle acquisizioni sotto carico effettuate con apparecchiatura RM dedicata, sono stati sottoposti a valutazione due gruppi di 20 soggetti, il primo composto da pazienti con diagnosi clinica di fascite plantare (A), l'altro da volontari sani $(B)$. In entrambi i gruppi nessuno dei soggetti riferiva in anamnesi patologie degenerative, traumatiche, neoplastiche ed infettive del piede, né patologie sistemiche (spondiliti sieronegative, gotta, artrite reumatoide, artrite psoriasica, sindrome di Reiter, ecc.); inoltre, $i$ pazienti (gruppo A) non erano stati sottoposti a terapie mini-invasive locoregionali, come le onde d'urto o le infiltrazioni di cortisonici, ma solo a terapia conservativa con anti-infiammatori non steroidei per os. L'età media nel gruppo A (16 uomini e 4 donne) era di 36 anni (range 24-45 anni), mentre quella nel gruppo B (14 uomini e 6 donne) era di 33 anni (range 20-41 anni).

Tutti i soggetti sono stati sottoposti ad esame RM con macchina dedicata da 0,25 Tesla (G-Scan, Esaote SpA, Genova, Italia), sia in posizione convenzionale, supina o in clinostatismo, che sotto carico fisiologico, in ortostatismo. Lo studio in quest'ultima posizione è stato eseguito utilizzando il sistema lettino/magnete basculato di circa $82^{\circ}$; la rotazione non è stata di $90^{\circ}$ per consentire di eseguire le valutazioni in carico gravitazionale quasi completo non ingenerando la possibile sensazione di instabilità. È stata usata una bobina di ricezione dedicata a forma di pedana (Fig. 1) e, per minimizzare le differenze di posizionamento, il piede è stato mantenuto solidale alla pedana per mezzo di una fascia, ottenendo, in questo modo, pressoché la stessa immagine scout di riferimento sia in ortostatismo che in clinostatismo e quindi piani approssimativamente equivalenti. L'indagine è stata condotta prima sotto carico e poi completata con le stesse sequenze in clinostatismo per ridurre al massimo il disagio dei pazienti, considerando anche la possibile insorgenza di ipotensione ortostatica, e gli eventuali artefatti da movimento. Sono state acquisite sequenze spin echo (SE) T1pesata (tempo di ripetizione [TR]/tempo di eco [TE] 800/26 $\mathrm{ms}$ ), turbo-spin echo (TSE) T2-pesata (TR/TE 2860/90 ms), short tau inversion recovery (STIR) (TR/TE/TI 4140/30/80 ms), e 3D-single-shot fast (SSF) T1-pesata (TR/TE 30/15 ms). La sequenza SE-T1 pesata impiegata nello studio è caratterizzata da un TR pari a $800 \mathrm{~ms}$ che, nell'esame RM dell'apparato muscolo- scheletrico, garantisce un contrasto ottimale (rispetto a TR particolarmente brevi) fra i tessuti coinvolti nell'indagine. In tutti i casi, sul piano sagittale sono state 


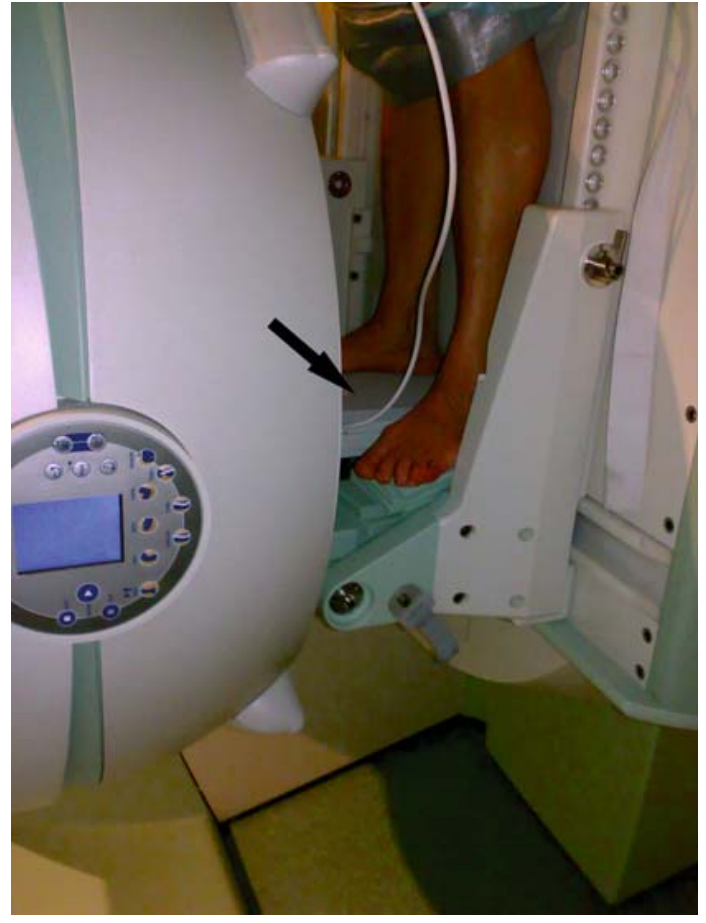

Fig. 1 G-Scan magnetic resonance imaging system with the gantry rotation of $82^{\circ}$ (weight-bearing position) and dedicated platform-shaped receiving coil (arrow) used in our study.

Fig. 1 Sistema RM G-Scan con gantry basculato di $82^{\circ}$ (posizione ortostatica); si evidenzia la bobina dedicata a forma di pedana (freccia) usata per acquisire le immagini.

Image reconstruction was therefore done on a $512 \times 512$ matrix, defined as "high resolution". Slice thickness and reconstruction intervals were $4 \mathrm{~mm}$ and $0.4 \mathrm{~mm}$ in all sequences except for the volumetric T1-weighted 3D-SSFP sequence, in which a 1.4-mm slice thickness was used. All examinations were performed without intravenous administration of gadolinium-based paramagnetic contrast material.

Images were sent via the local area network to the Radiology Information System/Picture Archiving and Communication System (RIS/PACS) (MedRIS Elefante Impax, AGFA Healthcare System) to enable direct comparison of images obtained in the inclined and upright positions on a workstation with a double monitor. Image evaluation was performed in consensus by three radiologists blinded to the group allocation of each individual and therefore to their history and clinical findings but not to the distinction between upright or inclined acquisition. Normally, the plantar fascia appears as a thin band $(2-4 \mathrm{~mm})$ with sharp and regular margins and low signal intensity in all sequences. MR characteristics of plantar fasciitis include: (1) fascia thickening, often with fusiform appearance, typically involving the proximal portion and extending to the calcaneal insertion; (2) abnormal signal intensity, which appears intermediate on T1- or proton- acquisite tutte le sequenze, mentre sul piano coronale sono state acquisite solo le sequenze TSE T2-pesata e STIR. Per tutte le sequenze è stato utilizzato un campo di vista (FOV) di $16 \mathrm{~cm}$ centrato sulla pianta del piede. Tutte le sequenze, fatta eccezione quella volumetrica 3D-SSF T1-pesata (per la quale è stata utilizzata una matrice di acquisizione di $224 \times 224$ ), sono caratterizzate, in acquisizione, da un numero di campionamenti nella direzione della lettura ed un numero di codifiche di fase nella direzione della codifica di fase maggiori di 256; la ricostruzione dell'immagine avviene quindi su una matrice di $512 \times 512$ pixel, definita "ad alta risoluzione". Lo spessore di strato e l'intervallo di ricostruzione usati erano di $4 \mathrm{~mm}$ e 0,4 $\mathrm{mm}$ in tutte le sequenze, fatta eccezione per la volumetrica 3D-SSF T1-pesata, in cui è stato utilizzato uno spessore di strato di 1,4 $\mathrm{mm}$. Tutte le indagini sono state eseguite senza la somministrazione endovenosa di mezzo di contrasto paramagnetico contenente gadolinio.

Le immagini ottenute sono state inviate via local area network (LAN) al sistema radiology information system (RIS)/picture archiving and communication system (PACS) (Sistema MedRIS ElefanteVmpax, AGFA Healthcare System) del nostro Istituto per avere la possibilità di un confronto diretto tra le immagini ottenute in clinostatismo e quelle in ortostatismo su workstation con doppio monitor. La valutazione delle immagini è stata effettuata in consenso da tre radiologi in cieco sull'appartenenza dei soggetti ai differenti gruppi, e quindi sulla loro anamnesi e l'obiettività clinica, ma non sulla distinzione tra la posizione di acquisizione delle sequenze, ortostatismo e clinostatismo. Normalmente la fascia plantare si presenta come una sottile banda $(2-4 \mathrm{~mm})$, a margini netti e regolari con bassa intensità di segnale in tutte le sequenze. Le caratteristiche RM della fascite plantare comprendono: 1) l'ispessimento della fascia, che spesso assume conformazione fusiforme, coinvolgente tipicamente la sua porzione prossimale ed esteso all'inserzione calcaneare; 2) l'alterazione dell'intensità di segnale, che si presenta intermedia nelle immagini pesate in $\mathrm{Tl}$ o densità protonica $(D P)$ e alta nelle immagini pesate in T2 o nelle STIR [1, 2, 10, 11]. Si può associare l'edema dei tessuti molli limitrofi superficiali e profondi, caratterizzato da aree scarsamente circoscritte ad alta intensità di segnale, che secondo alcuni autori è da solo un valido criterio diagnostico di fascite plantare [2]. Altro reperto che frequentemente si associa è l'edema dell'osso subcondrale della tuberosità calcaneare mediale $[1,2,10,11]$, nella maggior parte dei casi ad estensione limitata, che isolatamente non costituisce un criterio diagnostico della patologia.

Nel nostro studio è stata posta la diagnosi di fascite plantare in presenza di edema perifasciale o di entrambi i su esposti criteri. Le rotture vengono definite dai seguenti criteri: 1) l'ispessimento nella sede di rottura; 2) l'assenza (rottura completa) o la parziale perdita (rottura parziale) della normale intensità di segnale, che appare come 
density (PD)-weighted images and high in T2-weighted or STIR images $[1,2,10,11]$. Oedema of the surrounding superficial and deep soft tissues may be associated, characterised by poorly circumscribed areas of high signal intensity, which according to other authors is in itself a reliable diagnostic criterion for plantar fasciitis [2]. Another commonly associated finding is marrow oedema of the medial calcaneal tuberosity $[1,2,10,11]$, with limited extension in most cases, which on its own is not a diagnostic criterion for the disease

In our study the diagnosis of plantar fasciitis was made in the presence of perifascial oedema or both of the abovementioned criteria. Tears are defined by the following criteria: (1) thickening at the tear site; (2) absence (complete tear) or partial loss (partial tear) of normal signal intensity, which appears as an area of intermediate signal intensity on T1- or PD-weighted images and markedly hyperintense on T2-weighted or STIR images; and (3) hyperintensity on T2weighted and STIR images of the perifascial soft tissues due to oedema/haemorrhage $[1,2,11]$. Images obtained in the upright and supine positions were used to evaluate changes in: (1) morphodimensional features (thickness, morphology, margins); and (2) signal intensity of the plantar fascia and the surrounding perifascial structures, including the heel fat pad and the subchondral bone of the ankle. Accessory findings in the ankle and foot were also evaluated and reported, such as intra-articular effusion or tendon abnormalities. Plantar fascia thickness was measured using RIS/PACS system callipers in sagittal scans in the proximal, middle and distal segments at around 5, 20 and $40 \mathrm{~mm}$, respectively, from the calcaneal insertion. Plantar fascia thickening was defined as $>5 \mathrm{~mm}$ on the basis of the findings of Tsai et al. [6], who reported a fascial thickness of $3.83 \pm 0.72$ $\mathrm{mm}$ in the asymptomatic foot of patients with unilateral plantar fasciitis. Evaluations of changes in morphology and signal intensity were performed subjectively by comparing abnormal and normal findings and bearing in mind the abovementioned pathological criteria. Calcaneal marrow oedema and fascial lesion dimensions were quantified, and the extent of oedema was evaluated with a percentage estimate of its relative involvement with respect to plantar fascia thickness. Statistical analysis was done with the Intercooled STATA v. 9.0 software package (StataCorp LP). The values of dimensions of abnormalities objectively quantified were reported as mean \pm standard deviation (SD). Significance of the findings was calculated using the paired $t$ test, with $p<0.0001$.

\section{Results}

Evaluation of patient history and clinical examination

All individuals (100\%) in group A reported typical un'area a intensità intermedia, nelle immagini pesate in T1 o in DP e netta e marcatamente iperintensa nelle pesate in $T 2$ o in STIR; 3) l'iperintensità nelle sequenze T2 pesate e in STIR dei tessuti molli perifasciali, da edema/emorragia [1, 2, 11]. Sulle immagini ottenute, in ortostatismo ed in clinostatismo, sono state valutate le alterazioni: 1) morfo-dimensionali (spessore, morfologia, margini); 2) dell'intensità di segnale della fascia plantare e delle strutture limitrofe perifasciali, tra cui il cuscinetto adiposo sottocalcaneare, e l'osso subcondrale del calcagno. Sono stati valutati e riportati anche gli eventuali reperti accessori del piede e della caviglia, come il versamento endoarticolare o le alterazioni tendinee. Lo spessore della fascia plantare è stato misurato, utilizzando i calipers del sistema RIS/PACS, nelle scansioni sagittali nei tratti peri-inserzionale, medio e distale, rispettivamente a circa 5, 20 e $40 \mathrm{~mm}$ dall'inserzione calcaneare. Per la definizione dell'ispessimento è stato scelto uno spessore della fascia plantare $>5 \mathrm{~mm}$ in considerazione del riscontro effettuato da Tsai et al. [6] in US, i quali hanno osservato nel piede asintomatico di pazienti con fascite plantare monolaterale uno spessore della fascia plantare di $3,83 \pm 0,72 \mathrm{~mm}$. Le valutazioni delle alterazioni morfologiche e dell'intensità di segnale sono state eseguite in modo soggettivo, comparando i rilievi anomali con quelli normali e tenendo conto dei criteri patologici prima definiti, Sono state quantizzate le dimensioni dell'alterazione edematosa dell'osso subcondrale calcaneare e delle lesioni della fascia plantare; è stata valutata, inoltre, l'entità di questa stimando in percentuale il coinvolgimento relativo rispetto allo spessore della fascia plantare. Per l'analisi statistica è stato utilizzato il software Intercooled STATA v. 9.0 (StataCorp LP). I valori delle dimensioni di tutte le alterazioni quantizzate in modo oggettivo sono stati riportati come la media \pm la deviazione standard. La significatività dei risultati è stata calcolata usando il paired t test con $p<0,0001$.

\section{Risultati}

Valutazione dell'anamnesi e dell'obiettività clinica dei pazienti

Tutti i soggetti (100\%) del gruppo A, riferivano una sintomatologia tipica, insorta da 12,31 $\pm 4,98$ settimane (range 5-24 settimane), caratterizzata da dolore al tallone con $i$ primi passi dopo il riposo o insorgente al mattino; questo, inoltre, si acuiva durante l'attività motoria in modo esponenziale alla durata della stessa. La dorsiflessione passiva e la palpazione della porzione mediale del tallone erano fonte di dolorabilità in tutti i casi (100\%). Tutti i soggetti (100\%) del gruppo $B$, volontari, non riferivano sintomatologia algica degli arti inferiori e le manovre di dolorabilità non scatenavano alcuna sintomatologia algica. 
symptoms, with onset $12.31 \pm 4.98$ weeks (range 5-24 weeks) earlier and characterised by heel pain with the first few steps after rest or after rising in the morning. The pain tended to increase exponentially with motor activity duration. Passive dorsiflexion and palpation of the medial portion of the heel caused pain in all cases (100\%). All individuals (100\%) in group B reported no pain in the lower limb, and the abovementioned manoeuvres produced no pain.

Finding of plantar fasciitis

MR in both the inclined and upright positions enabled identification of plantar fasciitis, based on the defined criteria, in $15 / 20$ cases $(75 \%)$ in group A. In the remaining $5 / 20$ cases (25\%), the plantar fascia and perifascial soft tissues had normal appearance, although several associated abnormalities or accessory findings were observed (see below). MR imaging in both the inclined and upright positions revealed no abnormality referable to plantar fasciitis or any other type of pathological process in any of the 20 healthy volunteers in group B.

Measurement of the thickness of the plantar fascia

Plantar fascia thicknesses are reported in Table 1. In individuals with plantar fasciitis in group A, mean thickness in the proximal segment (the most common site of the condition) was $8.52 \pm 0.39 \mathrm{~mm}$ in the supine position and $8.1 \pm 0.43$ $\mathrm{mm}$ in the upright position, with a statistically significant $(p<0.0001)$ reduction in thickness during weight-bearing. Fascial thickness in the proximal segment in patients without plantar fasciitis was $4.64 \pm 0.09 \mathrm{~mm}$ in the supine position and $4.3 \pm 0.12 \mathrm{~mm}$ in the upright position, with a statistically significant $(p<0.0001)$ reduction in thickness. In group $\mathrm{B}$, in the supine position, mean fascial thickness in the proximal segment was $3.7 \pm 0.24 \mathrm{~mm}$, with a statistically significant $(p<0.0001)$ reduction in the upright position.

Evaluation of signal intensity of the plantar fascia

The $15 / 20$ cases (75\%) in group A with an MR diagnosis of plantar fasciitis showed the absence of homogeneous signal intensity in both the inclined and weight-bearing positions, with areas of heterogeneity that were intermediate in the T1-weighted SE sequences and high in the STIR and T2-weighted sequences (Fig. 2). In the remaining $5 / 20$ cases (25\%), no significant signal changes were observed in any of the sequences. Signal intensity of the plantar fascia was in normal range in all individuals in group $\mathrm{B}$, both in the inclined and the weight-bearing positions (Fig. 3).
Riscontro di fascite plantare

La RM, sia nelle acquisizioni in clinostatismo che in quelle in ortostatismo, ha consentito di definire la presenza della fascite plantare, tenendo conto dei criteri definiti, in 15/20 casi (75\%) nel gruppo A; nei restanti 5/20 casi (25\%) nel gruppo A è stato rilevato un normale aspetto della fascia plantare e dei tessuti molli perifasciali, ma sono state riscontrate alcune alterazioni associate o alcuni reperti accessori, riportati di seguito nella specifica sezione. In nessuno dei 20 volontari del gruppo controllo (B), nelle acquisizioni RM in entrambe le posizioni, sono state evidenziate alterazioni riferibili alla fascite plantare o ad altro tipo di patologia.

Misurazione dello spessore della fascia plantare

Gli spessori della fascia plantare sono riportati in Tabella 1. Nei casi con fascite plantare del gruppo A, lo spessore medio della fascia plantare nel tratto peri-inserzionale, sede elettiva della patologia, era di $8,52 \pm 0,39 \mathrm{~mm}$ in clinostatismo e $8,1 \pm 0,43 \mathrm{~mm}$ in ortostatismo, con evidenza statisticamente significativa $(p<0,0001)$ della riduzione dello spessore sotto carico; lo spessore in sede peri-inserzionale nei pazienti senza fascite plantare era 4,64 $\pm 0,09 \mathrm{~mm}$ in clinostatismo e $4,3 \pm 0,12 \mathrm{~mm}$ in ortostatismo, con riduzione statisticamente significativa $(p<0,0001)$ dello spessore. Nel gruppo $B$, in clinostatismo, lo spessore medio della fascia plantare era di $3,7 \pm 0,24 \mathrm{~mm}$ nel tratto peri-inserzionale con significative riduzioni dei valori $(p<0,0001)$, in ortostatismo.

Valutazione dell'intensità di segnale della fascia plantare

Nel gruppo A, nei 15/20 casi (75\%) con diagnosi RM di fascite plantare, è stato riscontrato, sia in ortostatismo che in clinostatismo, l'assenza dell'omogenea ipointensità di segnale della fascia plantare con presenza di area di disomogeneità, intermedia nella sequenza SE T1 pesata e alta nelle sequenze STIR e T2-pesate (Fig. 2). Nei restanti 5/20 casi $(25 \%)$ non è stata osservata una significativa alterazione di segnale in tutte le sequenze. L'intensità di segnale della fascia plantare è risultata nella norma in tutti $i$ soggetti del gruppo controllo (B), sia in clinostatismo che in ortostatismo (Fig. 3).

Valutazione delle interruzioni della continuità delle fibre fasciali

Nel gruppo A, in $4 / 15$ casi $(26,67 \%)$ con diagnosi $R M$ di fascite plantare è stata identificata, solo in ortostatismo, un'area di netta iperintensità di segnale in T2 nel contesto delle fibre fasciali, non chiaramente evidenziabile nella 
Table 1 Mean values and standard deviation (SD) of plantar fascia thickness in millimetres in patients, globally, with and without plantar fasciitis (group A) and volunteers (group B) compared in the upright weight-bearing and supine positions

\begin{tabular}{|c|c|c|c|c|c|c|c|c|c|}
\hline \multicolumn{10}{|c|}{ Statistical analysis of plantar fascia thickness } \\
\hline Subgroup & & Global & & & $\mathrm{PF}$ & & & WPF & \\
\hline Segment/position & Supine & WB & $p$ value & Supine & WB & $p$ value & Supine & WB & $p$ value \\
\hline \multicolumn{10}{|l|}{ Group A } \\
\hline Proximal & $7.55 \pm 1.76$ & $7.2 \pm 1.73$ & $<0.0001$ & $8.52 \pm 0.39$ & $8.1 \pm 0.43$ & $<0.0001$ & $4.64 \pm 0.09$ & $4.3 \pm 0.12$ & $<0.0001$ \\
\hline Middle & $2.3 \pm 0.38$ & $2 \pm 0.35$ & $<0.0001$ & $2.47 \pm 0.25$ & $2.16 \pm 0.23$ & $<0.0001$ & $1.78 \pm 0.08$ & $1.52 \pm 0.11$ & $<0.0001$ \\
\hline Distal & $1.3 \pm 0.11$ & $1.3 \pm 0.11$ & 1 & $1.3 \pm 0.11$ & $1.3 \pm 0.11$ & 1 & $1.2 \pm 0.05$ & $1.2 \pm 0.05$ & 1 \\
\hline \multicolumn{10}{|l|}{ Group B } \\
\hline Proximal & $3.7 \pm 0.24$ & $3.5 \pm 0.20$ & $<0.0001$ & - & - & - & - & - & - \\
\hline Middle & $1.8 \pm 0.13$ & $1.6 \pm 0.11$ & $<0.0001$ & - & - & - & - & - & - \\
\hline Distal & $1.2 \pm 0.12$ & $1.2 \pm 0.12$ & 1 & - & - & - & - & - & - \\
\hline
\end{tabular}

$W B$, weight bearing; $P F$, plantar fasciitis; $W F P$, without plantar fasciitis

Tabella 1 Valori medi e deviazioni standard dello spessore della fascia plantare riportati in mm nei pazienti, considerati globalmente, con e senza fascite plantare (parte A) e nei volontari sani (parte B) confrontati in clinostatismo e ortostatismo

\begin{tabular}{|c|c|c|c|c|c|c|c|c|c|}
\hline $\begin{array}{l}\text { Sottogruppo } \\
\text { Tratto/Posizione }\end{array}$ & Clino & $\begin{array}{l}\text { Globale } \\
\text { Orto }\end{array}$ & $p$ & Clino & $\begin{array}{l}\text { FP } \\
\text { Orto }\end{array}$ & $p$ & Clino & $\begin{array}{l}\text { NFP } \\
\text { Orto }\end{array}$ & $p$ \\
\hline \multicolumn{10}{|l|}{ Gruppo A } \\
\hline Peri-inserzionale & $7,55 \pm 1,76$ & $7,2 \pm 1,73$ & $<0,0001$ & $8,52 \pm 0,39$ & $8,1 \pm 0,43$ & $<0,0001$ & $4,64 \pm 0,09$ & $4,3 \pm 0,12$ & $<0,0001$ \\
\hline Medio & $2,3 \pm 0,38$ & $2 \pm 0,35$ & $<0,0001$ & $2,47 \pm 0,25$ & $2,16 \pm 0,23$ & $<0,0001$ & $1,78 \pm 0,08$ & $1,52 \pm 0,11$ & $<0,0001$ \\
\hline Distale & $1,3 \pm 0,11$ & $1,3 \pm 0,11$ & 1 & $1,3 \pm 0,11$ & $1,3 \pm 0,11$ & 1 & $1,2 \pm 0,05$ & $1,2 \pm 0,05$ & 1 \\
\hline \multicolumn{10}{|l|}{ Gruppo B } \\
\hline Peri-inserzionale & $3,7 \pm 0,24$ & $3,5 \pm 0,20$ & $<0,0001$ & - & - & - & - & - & - \\
\hline Medio & $1,8 \pm 0,13$ & $1,6 \pm 0,11$ & $<0,0001$ & - & - & - & - & - & - \\
\hline Distale & $1,2 \pm 0,12$ & $1,2 \pm 0,12$ & 1 & - & - & - & - & - & - \\
\hline
\end{tabular}

Clino, clinostatismo; Orto, ortostatismo; FP, fascite plantare; NFP, non fascite plantare

Evaluation of interruptions in the fascial fibres

In $4 / 15$ cases $(26 \%-67 \%)$ in group A with a diagnosis of plantar fasciitis, an area of marked T2-signal hyperintensity was identified only in the upright position, being less clearly visualised in the supine position given the absence of a clear interruption of fascial fibres (Fig. 4). The area of the lesion was visible in both the sagittal and coronal planes (Fig. $5 \mathrm{a}-\mathrm{e})$. The width of the area (anteroposterior diameter) was $1.9 \pm 0.47 \mathrm{~mm}$ (range 1.5-2.5 $\mathrm{mm}$ ), whereas the thickness (craniocaudal diameter) was $2.75 \pm 0.65$, and the extent of the lesion with respect to the thickness of the plantar fascia $(7.75 \pm 0.65 \mathrm{~mm}$ ) was $35.24 \pm 6.33 \%$ (range $28.6 \%-44.75 \%$ ). In the remaining $11 / 15$ patients in group $A$ with a diagnosis of plantar fasciitis, in the $5 / 20$ patients without a diagnosis of plantar fasciitis and in the healthy volunteers, no signal changes attributable to focal interruptions of the fascial fibres were found in either the inclined or the upright position. posizione supina, in assenza di netta interruzione dei margini della fascia (Fig. 4). L'area di lesione è risultata visibile sia sul piano sagittale che su quello coronale (Fig. 5). L'ampiezza (diametro antero-posteriore) dell'area era

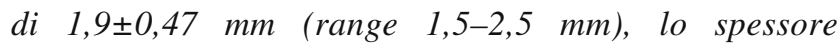
(diametro cranio-caudale) di 2,75 $\pm 0,65 \mathrm{~mm}$ (range 2-3,5 $\mathrm{mm}$ ) e l'entità della lesione rispetto allo spessore della fascia plantare $(7,75 \pm 0,65 \mathrm{~mm}$ ) di 35,24\% $\pm 6,33 \%$ (range 28,6\%-44,75\%). Nei restanti $11 / 15$ pazienti del gruppo $A$ con diagnosi di fascite plantare, nei 5/20 pazienti senza diagnosi di fascite plantare e nei volontari sani non sono state rilevate alterazioni riferibili a interruzioni focali della continuità delle fibre fasciali sia in clinostatismo che in ortostatismo.

Alterazioni associate del calcagno e dei tessuti molli perifasciali, e reperti accessori

In Tabella 2 sono riportate le incidenze dei reperti nei 

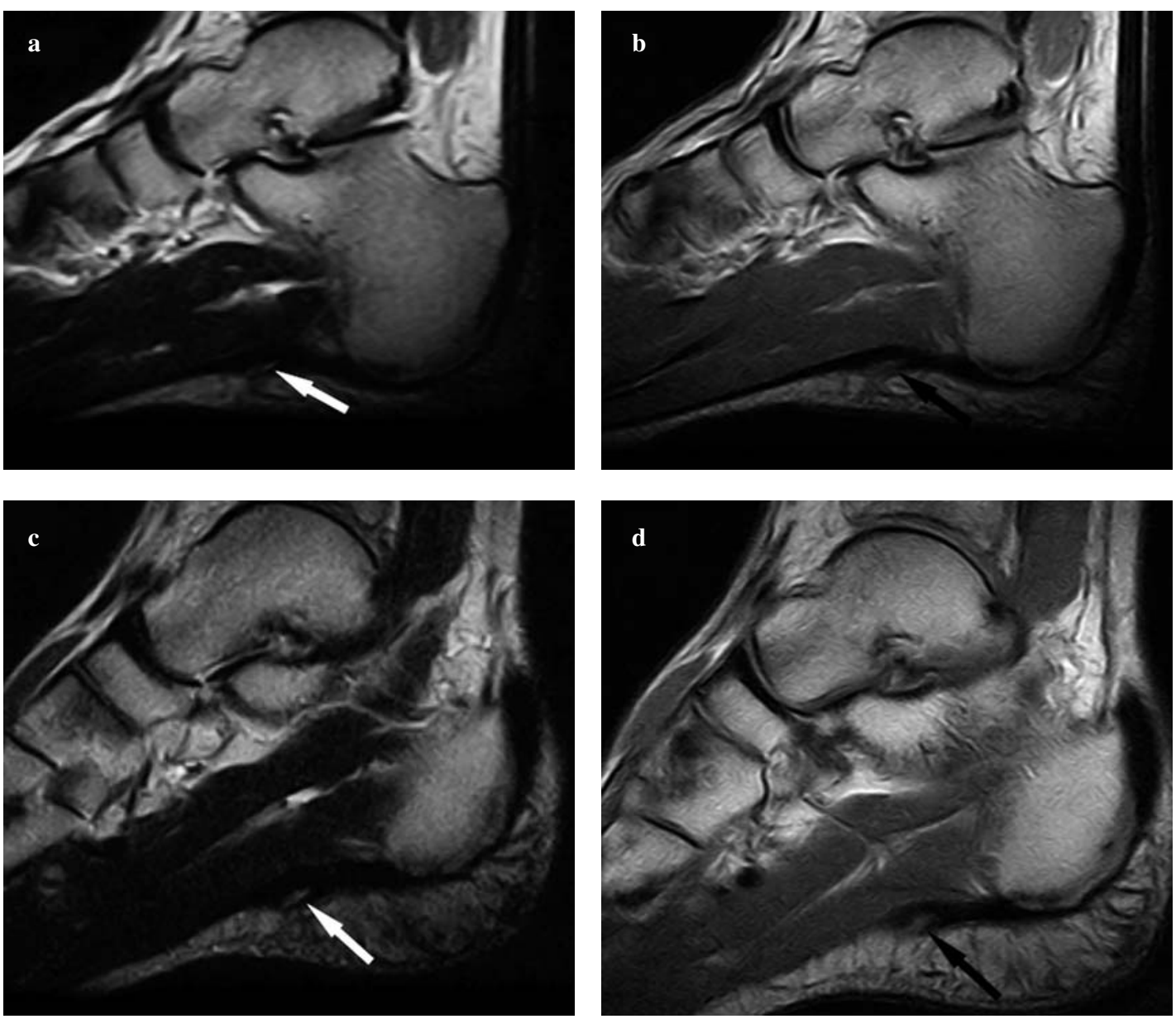

Fig. 2a-d Sagittal T2-weighted turbo spin echo (a) and T1-weighted spin echo (b) images in the supine position and corresponding images (c, d) in the weight-bearing position of the same individual with plantar fasciitis (group A). In the weight-bearing position, a focal area of sharp increase in interfibrillar signal of the superficial portion of plantar fascia appears more clearly defined (arrows).

Fig. 2a-d Scansioni sagittali TSE T2-pesata (a) e SE T1-pesata (b) in clinostatismo, e rispettive sequenze in ortostatismo (c,d) di uno stesso soggetto con fascite plantare (gruppo A). In ortostatismo appare meglio definita l'area focale di netto incremento di segnale del versante superficiale della fascia plantare (frecce).

Changes associated with the ankle and perifascial soft tissues, and accessory findings

Table 2 reports the incidence of findings in individuals with and without plantar fasciitis and in healthy volunteers. Calcaneal marrow oedema was found in $5 / 15$ patients $(33.33 \%)$ with plantar fasciitis and in $2 / 5(40 \%)$ with no evidence of plantar fasciitis. Moreover, in the five cases with plantar fasciitis, marrow oedema thickness was $11.43 \pm 17.12 \mathrm{~mm}$ (range $2-50 \mathrm{~mm}$ ), with an extension of $10.28 \pm 11.07 \mathrm{~mm}$ (range $4-35 \mathrm{~mm}$ ). In the other two cases without plantar fasciitis, the thickness was $3 \pm 1.4 \mathrm{~mm}$ (range 2-4 mm) with an extension of 3.5 $\pm 0.7 \mathrm{~mm}$ (range 3-4 mm). In group A, a heel spur was present in 7/15 (46.67\%) patients with plantar fasciitis, and in $2 / 7$ of these $(28.57 \%)$, there was associated marrow oedema. All associated pazienti con e senza fascite plantare e nei volontari sani. L'edema dell'osso subcondrale calcaneare è stato evidenziato in 5/15 (33,33\%) casi tra i pazienti con fascite plantare ed in 2/5 (40\%) casi tra i pazienti senza evidenza di fascite plantare; inoltre, lo spessore dell'edema osseo era, nei 5 casi con fascite plantare, di 11,43 $\pm 17,12 \mathrm{~mm}$ (range 2-50 mm) con un'estensione 10,28 $\pm 11,07 \mathrm{~mm}$ (range 4-35 $\mathrm{mm})$, mentre, negli altri 2 casi senza fascite plantare, lo

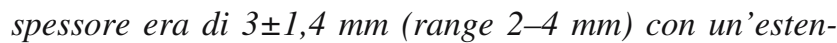
sione di 3,5 $\pm 0,7 \mathrm{~mm}$ (range 3-4 mm). Nel gruppo dei pazienti (A) era presente uno sperone calcaneare in $7 / 15$ $(46,67 \%)$ casi tra i pazienti con fascite plantare, in $2 / 7$ (28,57\%) dei quali questo si associava all'edema osseo subcondrale. Tutte le alterazioni associate e i reperti accessori sono state evidenziate in egual misura nelle acquisizioni RM in clinostatismo e sotto carico. 

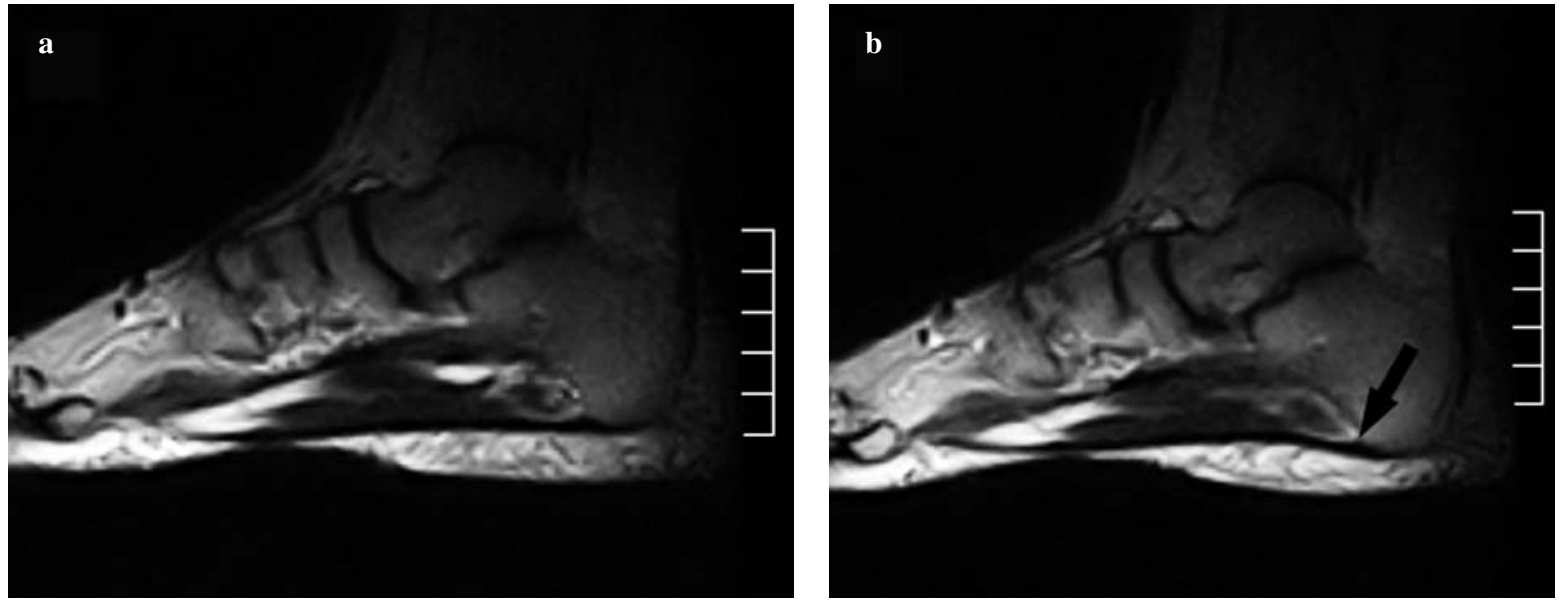

Fig. 3a,b Sagittal T2-weighted turbo spin echo images in the supine (a) and weight-bearing positions (b) show the plantar fascia of the same individual (group B) with normal signal intensity and increased tension of the plantar fascia under physiological load (arrow).

Fig. 3a,b Scansioni sagittali TSE T2-pesata in clinostatismo (a) ed in ortostatismo (b) che evidenziano la fascia plantare di uno stesso soggetto (gruppo B) con normale intensità di segnale ed evidente aumento di tensione della fascia plantare sotto carico fisiologico (freccia).
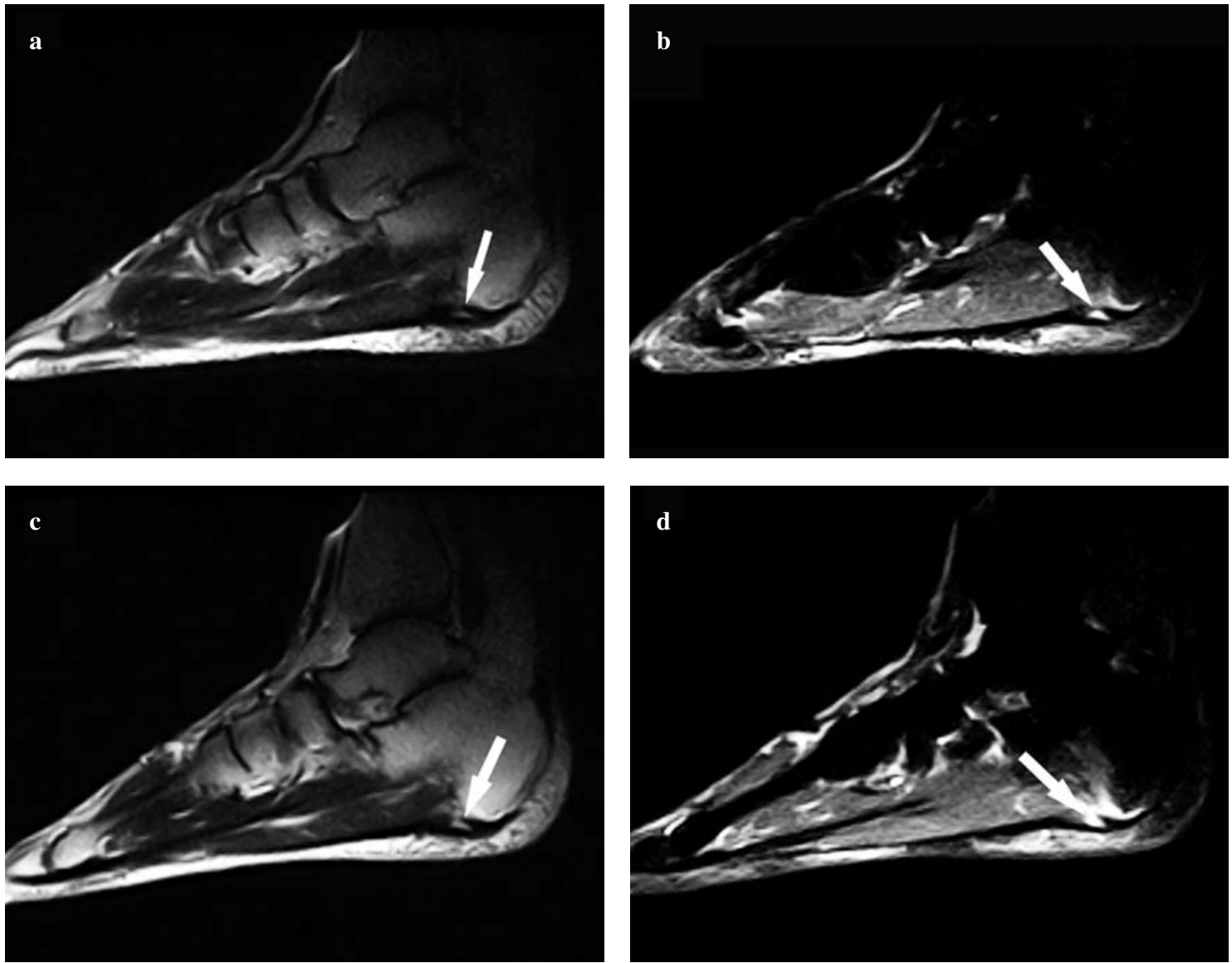

Fig. 4a-d Sagittal T2-weighted turbo spin echo (a) and short-tau inversion recovery (b) images in the supine position and corresponding images (c, d) in the weight-bearing position of the same patient with plantar fasciitis (group A). Weight-bearing images better depict the fascial tear in the deep portion, probably because of increased tension exerted on the fascial fibres, and calcaneal marrow oedema.

Fig. 4a-d Scansioni sagittali TSE T2-pesata (a) e STIR (b) in clinostatismo e rispettive sequenze in ortostatismo (c,d) di uno stesso soggetto con fascite plantare (gruppo A). In ortostatismo è maggiormente evidente la rottura fasciale sul versante profondo (frecce), probabilmente per la maggiore tensione esercitata sulle fibre fasciali, e l'edema osseo calcaneare. 

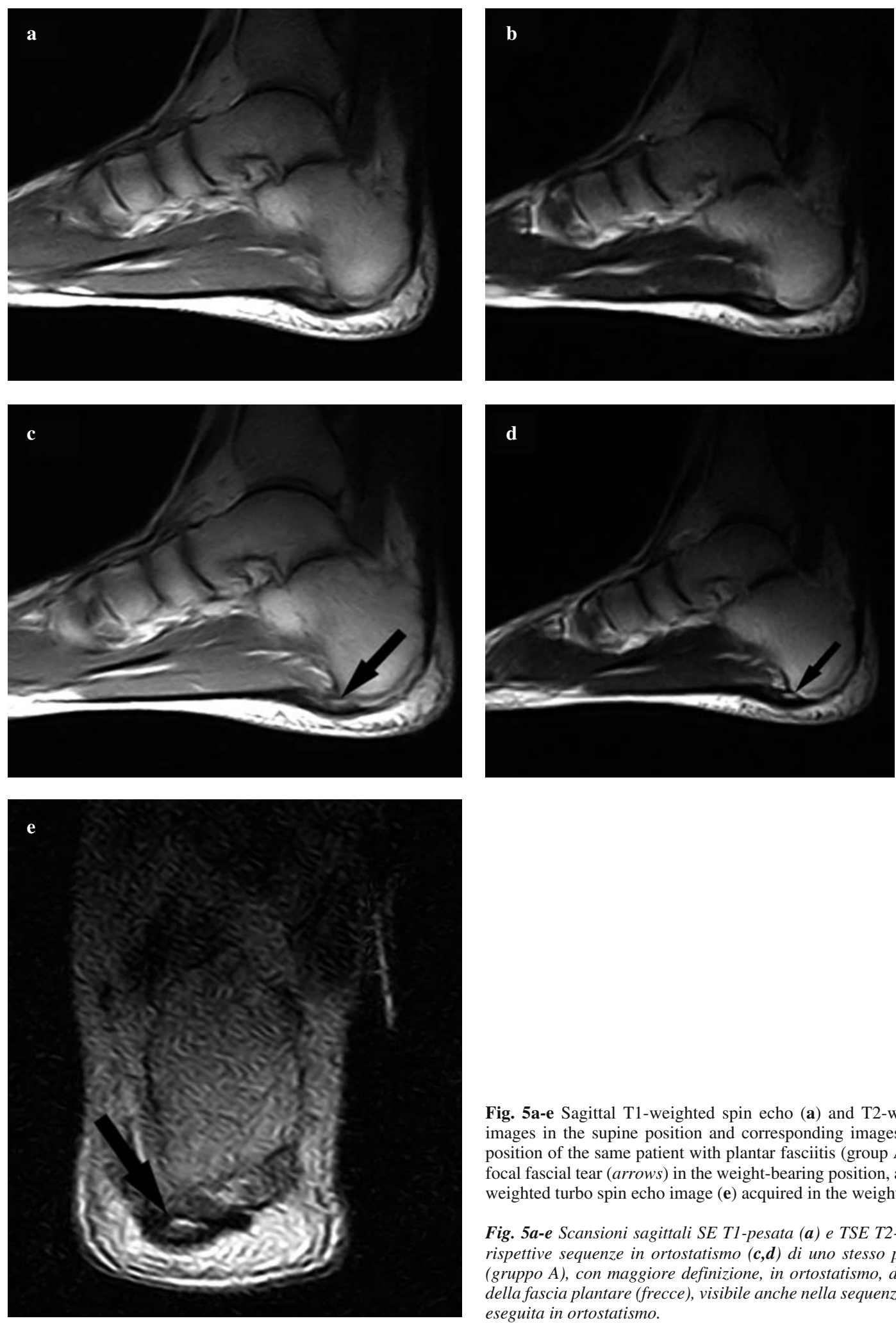

Fig. 5a-e Sagittal T1-weighted spin echo (a) and T2-weighted turbo spin echo (b) images in the supine position and corresponding images $(\mathbf{c}, \mathbf{d})$ in the weight-bearing position of the same patient with plantar fasciitis (group A), with better definition of a focal fascial tear (arrows) in the weight-bearing position, also visible in the coronal T2weighted turbo spin echo image (e) acquired in the weight-bearing position.

Fig. 5a-e Scansioni sagittali SE T1-pesata (a) e TSE T2-pesata (b) in clinostatismo e rispettive sequenze in ortostatismo $(\boldsymbol{c}, \boldsymbol{d})$ di uno stesso paziente con fascite plantare (gruppo A), con maggiore definizione, in ortostatismo, di una focale rottura parziale della fascia plantare (frecce), visibile anche nella sequenza coronale TSE T2-pesata (e) eseguita in ortostatismo. 
Table 2 Magnetic resonance (MR) imaging findings: fascial and perifascial alterations and accessory findings

\begin{tabular}{llll}
\hline $\begin{array}{l}\text { MR findings } \\
\text { Group }\end{array}$ & A & & \\
Subgroup & PF & A & BPF \\
WPF & $0 / 20(0 \%)$ \\
Thickened fascia & $15 / 15(100 \%)$ & $0 / 5(0 \%)$ & $0 / 20(0 \%)$ \\
Intrafascial signal intensity & $15 / 15(100 \%)$ & $0 / 5(0 \%)$ & $0 / 20(0 \%)$ \\
Plantar fascia tear & $4 / 15(26.67 \%)$ & $0 / 5(0 \%)$ & $0 / 20(0 \%)$ \\
Perifascial oedema & $6 / 15(40 \%)$ & $0 / 5(0 \%)$ & $0 / 20(0 \%)$ \\
Bone marrow oedema & $5 / 15(33.33 \%)$ & $2 / 5(40 \%)$ & $0 / 20(0 \%)$ \\
Heel spur & $7 / 15(46.67 \%)$ & $1 / 5(20 \%)$ & $0 / 20(0 \%)$ \\
Tibiotarsal joint effusion & $0 / 15(0 \%)$ & $5 / 5(100 \%)$ & $0 / 20(0 \%)$ \\
Achilles tendinopathy & $0 / 15(0 \%)$ & $2 / 5(40 \%)$ & \\
\hline
\end{tabular}

$P F$, plantar fasciitis; WFP, without plantar fasciitis

Tabella 2 Rilievi RM: alterazioni della fascia plantare e delle strutture perifasciali, e reperti accessori

\begin{tabular}{llll}
\hline $\begin{array}{l}\text { Rilievi RM } \\
\text { Gruppo }\end{array}$ & A & A & $B$ \\
Sottogruppo & $F P$ & $N F P$ & $N F P$ \\
\hline Ispessimento fascia plantare & $15 / 15(100 \%)$ & $0 / 5(0 \%)$ & $0 / 20(0 \%)$ \\
Disomogeneità segnale fascia plantare & $15 / 15(100 \%)$ & $0 / 5(0 \%)$ & $0 / 20(0 \%)$ \\
Lesioni fascia plantare & $4 / 15(26,67 \%)$ & $0 / 5(0 \%)$ & $0 / 20(0 \%)$ \\
Edema perifasciale & $6 / 15(40 \%)$ & $0 / 5(0 \%)$ & $0 / 20(0 \%)$ \\
Edema dell'osso subcondrale calcaneare & $5 / 15(33,33 \%)$ & $2 / 5(40 \%)$ & $0 / 20(0 \%)$ \\
Sperone calcaneare & $7 / 15(46,67 \%)$ & $1 / 5(20 \%)$ & $0 / 20(0 \%)$ \\
Versamento articolare tibio-tarsico & $0 / 15(0 \%)$ & $5 / 5(100 \%)$ & $0 / 20(0 \%)$ \\
Tendinopatia achillea & $0 / 15(0 \%)$ & $2 / 5(40 \%)$ & $0 / 20(0 \%)$ \\
\hline
\end{tabular}

FP, fascite plantare; NFP, non fascite plantare

changes and accessory findings were found in equal measure in MR scans acquired in the inclined and the weight-bearing positions.

\section{Discussion}

Plantar fasciitis is the most common cause of hind-foot pain and is characterised by an inflammatory process that involves the plantar aponeurosis with or without associated involvement of perifascial structures. This process may be caused by a number of factors that, in general, can be classified according to three broad categories: mechanical, degenerative and systemic [2, 3, 11].

An important cause of plantar fasciitis is clearly excessive motion in the foot during gait and the tension forces that the plantar fascia undergoes in some endurance sports (long-distance walking, running) or jumping sports (basketball, dancing, volleyball) $[1,11]$. Indeed, some authors [9, 12] have emphasised the fundamental role of the plantar fascia in absorbing shock during the first phase of gait, whereas in the second phase, it acts as a cord. In addition, in these two positions, the plantar system is under tension and therefore contributes to protecting the foot.

\section{Discussione}

La fascite plantare è la causa più frequente di dolore del retropiede e consiste in un processo infiammatorio che coinvolte l'aponeurosi plantare senza o con associato coinvolgimento delle strutture perifasciali. Tale processo può risultare da un certo numero di cause, che, in generale, vengono riassunte in tre grandi categorie: meccaniche, degenerative e sistemiche [2, 3, 11].

Un ruolo importante nella determinazione di tale patologia è dato chiaramente dall'esasperato dinamismo del movimento del passo e dalle forze vettoriali alle quali è sottoposta la fascia plantare in alcuni sport di durata (marcia, fondo) o che richiedono continui salti (pallacanestro, danza, pallavolo) [1, 11]. Infatti, secondo alcuni autori [9, 12], la fascia plantare ha un ruolo fondamentale nell'assorbire lo shock durante la prima parte del passo, laddove nella seconda parte agisce come una corda; inoltre, in queste due posizioni, il sistema muscolo-aponeurotico plantare è sotto tensione, e contribuisce, pertanto, alla protezione del piede.

L'US è una metodica molto valida per lo studio della fascite plantare, grazie alla sua eccellente risoluzione spaziale, tuttavia non ha la stessa sensibilità della RM, è una tecnica fortemente operatore dipendente e non permette 
Ultrasound is a highly valid technique for studying plantar fasciitis, thanks to its excellent spatial resolution. However, it does not have the same sensitivity as MR imaging, it is highly operator-dependent and is unable to identify associated changes such as calcaneal marrow oedema [5-7]. In the diagnostic phase, MR imaging has the undeniable advantage of providing an overall structural and morphological evaluation, with the possibility of evaluating the course, thickness, margins and signal intensity of the plantar fascia, as well as distinguishing between the different types of abnormalities [1-3, 8-11].

All patients in group A had the typical symptoms, with onset $12.31 \pm 4.98$ weeks earlier, therefore tending towards a chronic condition, which is defined as being present for a lengthy period, typically longer than 6 months [13]. An MR diagnosis of plantar fasciitis was formulated based on the imaging features described above (focal increase in fascial thickness and abnormal intrafascial and/or perifascial signal) in only $15 / 20$ cases $(75 \%)$. In the remaining $5 / 20$ patients $(25 \%)$, associated changes only were identified (marrow oedema and heel spur) or accessory findings (tibiotarsal intra-articular effusion and Achilles' tendinopathy). In none of patients in group B were abnormalities observed in the plantar fascia or in other assessable structures. No differences were observed in the identification of plantar fasciitis with MR scans in the two positions. In all cases with an MR diagnosis of plantar fasciitis (100\%), we observed an increased thickness of the proximal portion of the plantar fascia, which is the most common site of the condition, both in the inclined and the upright positions, equivalent to $8.52 \pm 0.39 \mathrm{~mm}$ and $8.1 \pm 0.43 \mathrm{~mm}$, respectively. Other authors have reported this finding in up to $58 \%$ of cases [1,2]. Proximal plantar fascia thickness in the volunteers and the five remaining patients in group A was within the normal range, both in the supine position $(3.7 \pm 0.23$ and $4.64 \pm 0.09 \mathrm{~mm}$, respectively) and the weight-bearing position $(3.5 \pm 0.2 \mathrm{~mm}$ and $4.3 \pm 0.12 \mathrm{~mm}$, respectively). We observed a greater thickness in patients than in volunteers, but this aspect was not followed up, as it was not among the aims of our study. In patients with plantar fasciitis, a relative thickening of the middle portion was also identified with respect to individuals without the condition. The difference was statistically significant $(p<0.0001)$ and is most likely attributable to a functional adaptation, which produces a change in size in the absence of signal intensity changes. A significant reduction $(p<0.0001)$ was observed in fascial thickness between scans acquired in the supine position and those in the weight-bearing position in the proximal and middle portions but not in the distal portion $(p=0.0078)$ both in groups. A possible explanation is the different architectural and arrangement of the fascial fibres, which are more malleable in the proximal and middle portions and there- di riscontrare alterazioni associate come l'edema dell'osso subcondrale calcaneare [5-7]. In fase diagnostica, la RM presenta l'indubbio vantaggio di permettere la valutazione morfologica e strutturale globale, con possibilità di valutare il decorso, lo spessore, i margini, e l'intensità di segnale della fascia plantare, nonché di distinguere i differenti tipi di alterazioni [1-3, 8-11].

Tutti i pazienti del gruppo A presentavano una sintomatologia tipica insorta da 12,31 $\pm 4,98$ settimane, inquadrabile quindi come una forma tendente alla cronicizzazione, considerato che vengono definite tali quelle insorte da lungo tempo, tipicamente da più di 6 mesi [13]. La diagnosi RM di fascite plantare è stata formulata, in considerazione dei criteri semeiologici descritti (aumento focale dello spessore fasciale e un'alterazione del segnale intrafasciale elo perifasciale), solo in 15/20 casi (75\%); nei restanti 5/20 pazienti (25\%) sono state osservate solo alterazioni associate (edema osseo e spina calcaneare) o reperti accessori (versamento endoarticolare tibio-tarsico e tendinopatia achillea). In nessuno dei pazienti del gruppo B è stata evidenziata alcuna alterazione della fascia plantare e delle altre strutture valutabili. Non è stata evidenziata alcuna differenza nell'identificazione dei casi con fascite plantare nelle acquisizioni RM nelle due posizioni. In tutti i casi con diagnosi RM di fascite plantare $(100 \%)$ abbiamo osservato un incremento dello spessore della fascia plantare nel tratto peri-inserzionale, sede elettiva della patologia, sia in clinostatismo che in ortostatismo rispettivamente di 8,52 $\pm 0,39 \mathrm{~mm}$ e $8,1 \pm 0,43 \mathrm{~mm}$; altri autori hanno rilevato un'incidenza del reperto al massimo nel $58 \%$ dei casi [1, 2]. Lo spessore della fascia plantare nel tratto peri-inserzionale nei volontari e nei 5 pazienti rimanenti del gruppo A era nei limiti della norma sia in clinostatismo, 3,7 $\pm 0,23 \mathrm{~mm}$ e 4,64 $\pm 0,09 \mathrm{~mm}$, che in ortostatismo, 3,5 $\pm 0,2$ mm e 4,3 $\pm 0,12 \mathrm{~mm}$, rispettivamente; abbiamo osservato uno spessore maggiore nei pazienti rispetto ai volontari, ma l'aspetto non è stato approfondito non rientrando tra gli scopi dello studio. Nei pazienti con fascite plantare è stato rilevato anche un ispessimento relativo del tratto medio della fascia plantare rispetto a quelli senza; la differenza è risultata statisticamente significativa $(p<0,0001)$ ed è da ascrivere verosimilmente a un adattamento funzionale che esita in un'alterazione dimensionale in assenza di alterazioni dell'intensità di segnale. Sia nel gruppo A che nel gruppo $B$ abbiamo rilevato una significativa riduzione $(p<0,0001)$ dello spessore della fascia plantare tra le acquisizioni in clinostatismo e quelle sotto carico solo nei tratti peri-inserzionale e medio ma non nel tratto distale $(p=0,0078)$. Una probabile spiegazione potrebbe risiedere nella differente architettura e disposizione delle fibre della fascia plantare, più malleabili in corrispondenza di tratti peri-inserzionale $e$ medio, che pertanto risentirebbero maggiormente della tensione a cui sono sottoposte sotto carico.

In tutti i casi con diagnosi RM di fascite plantare (100\%) 
fore probably more heavily affected by the tension they undergo during weight-bearing.

In all cases with an MR diagnosis of plantar fasciitis (100\%), there was an absence of homogenous low signal intensity of the fascia and the presence of areas of signal heterogeneity, which was intermediate in the T1-weighted SE sequence and high in the STIR and T2-weighted sequences. Other authors have reported this finding in up to $52 \%$ of cases $[1,2]$. A fascial tear, whether complete or partial, is an uncommon diagnosis in that not only does it occur infrequently but it is often overlooked [1-3, 8, 14]. In most cases, the condition affects runners who subject the plantar fascia to considerable force during acceleration, or it can be the result of a repetitive trauma in amateur athletes engaging in sports involving running and jumping. In other cases, however, a spontaneous tear of the plantar fascia is possible in patients with prior plantar fasciitis, especially in those treated with local injections of corticosteroids (10\% of treated cases according to some studies) $[1-3,8,14]$. In $4 / 15$ cases $(26.67 \%)$ with an MR diagnosis of plantar fasciitis, an area of marked T2 hyperintensity was identified in the fascial fibres only in the upright position in the absence of a clear interruption of the fascial margins.

The area of the lesion visible in both the sagittal and coronal planes had a width of $1.9 \pm 0.47 \mathrm{~mm}$ and a thickness of $2.75 \pm 0.65 \mathrm{~mm}$, with lesion extent relative to plantar fascia thickness of $35.24 \% \pm 6.33 \%$. This finding was interpreted as a partial intrafascial tear. A possible explanation for visualisation of these lesions only in the upright weightbearing position is that the tension of the fascial fibrils subjected to traction during weight bearing extends the microlesions, which are of limited extent and contained within the fascia and thus latent in the supine position. In the other patients in group A and in the healthy volunteers, no abnormalities attributable to focal interruptions of the fascial fibres were identified in either the inclined or upright position. In patients with an MR diagnosis of plantar fasciitis, perifascial oedema was identified in only $40 \%$ of cases and always associated with changes in fascial dimensions and signal intensity, in contrast to previous reports according to which this is one of the most frequent findings (70\%-100\% of cases) and in many cases the sole finding $[1,2,8]$. Perifascial oedema was not observed in the $5 / 20$ patients without evidence of plantar fasciitis or in group B individuals.

Marrow oedema was identified in $33.33 \%$ of cases of plantar fasciitis, in agreement with the incidence reported in the literature (17\%-56\% of cases) $[1,2]$, with thickness and extension of $11.43 \pm 17.12 \mathrm{~mm}$ and $10.28 \pm 11.07 \mathrm{~mm}$. In one of these cases, the oedema was extensive (maximum diameter $4 \mathrm{~cm}$ ) and not limited to the calcaneal insertion, as commonly reported in the literature $[1,2,10,11]$. In cases è stata riscontrata, in entrambe le posizioni, l'assenza dell'omogenea ipointensità di segnale della fascia plantare con presenza di area di disomogeneità, intermedia nella sequenza SE T1-pesata ed alta nelle sequenze STIR e T2pesata; altri autori riportavano un'incidenza di tale reperto al massimo nel 52\% dei casi [1,2]. La rottura della fascia plantare, sia completa che parziale, è una diagnosi poco comune, dal momento che oltre ad essere poco frequente, spesso non viene riconosciuta [1-3, 8, 14]. Nella maggior parte dei casi colpisce atleti agonisti che sottopongono la fascia plantare a notevoli forze durante la fase di accelerazione della corsa, oppure può essere la risultante di un trauma ripetitivo negli atleti amatoriali che praticano corsa e salto. In altri casi, è, comunque, possibile una rottura spontanea della fascia plantare nei pazienti con sovrapposta fascite plantare, specialmente in quelli trattati con iniezioni locali di corticosteroidi $(10 \%$ dei casi trattati secondo alcuni studi) $[1-3,8,14]$. In $4 / 15$ casi $(26,67 \%)$ con diagnosi RM di fascite plantare è stata identificata, solo in ortostatismo, nel contesto delle fibre fasciali, un'area di netta iperintensità di segnale in $T 2$, in assenza di netta interruzione dei margini della fascia.

L'area di lesione visibile sia sul piano sagittale che su

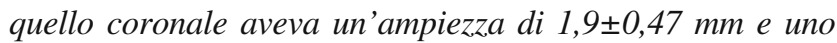
spessore di 2,75 $\pm 0,65 \mathrm{~mm}$ con un'entità della lesione rispetto allo spessore della fascia plantare del $35,24 \% \pm 6,33 \%$. Il reperto è stato interpretato come una rottura parziale intrafasciale. Possibile ipotesi che giustifichi l'evidenza di queste lesioni solo in ortostatismo potrebbe essere che la tensione delle fibrille fasciali sottoposte a trazione sotto carico amplierebbe le microlesioni, poco estese e contenute nello spessore fasciale, latenti in clinostatismo. Negli altri pazienti del gruppo A e nei volontari sani non sono state rilevate alterazioni riferibili a interruzioni focali della continuità delle fibre fasciali sia in clinostatismo che in ortostatismo. Nei pazienti con diagnosi RM di fascite plantare l'edema perifasciale è stato evidenziato soltanto nel $40 \%$ dei casi e sempre associato ad alterazioni dimensionali e dell'intensità di segnale della fascia, contrariamente a quanto riscontrato da altri autori, secondo cui questo è uno dei reperti più frequentemente osservati (tra il $70 \%$ ed il $100 \%$ dei casi) ed in molti casi viene riscontrato in modo isolato [1, 2, 8]; tale reperto non è stato osservato nei 5/20 casi senza evidenza di fascite plantare né nei soggetti del gruppo $B$.

L'edema dell'osso subcondrale calcaneare è stato evidenziato nei pazienti con fascite plantare nel 33,33\% dei casi, in accordo con l'incidenza riportata in letteratura (tra il $17 \%$ e il 56\% dei casi) [1, 2], con spessore ed estensione di $11,43 \pm 17,12 \mathrm{~mm}$ e 10,28 $\pm 11,07 \mathrm{~mm}$; in uno dei casi è stato osservato un edema osseo di notevole estensione (diametro massimo $5 \mathrm{~cm}$ ), non limitato alla sede peri-inserzionale come comunemente riportato in letteratura [1, 2, 10, 11]. Nei casi senza evidenza di fascite plantare l'edema osseo è stato 
without evidence of plantar fasciitis, marrow oedema was identified in $40 \%$ of cases (2/5), with limited dimensions (maximum diameter $4 \mathrm{~mm}$ ), and was probably the consequence of microtraumas due to overloading.

The accessory finding of a heel spur was identified in $46.67 \%$ of cases with plantar fasciitis, but as other authors have noted, the correlation of this finding is random and is of no relevance [1, 3, 9-11, 13]. Associated and accessory findings were identified in an equal amount, without significant differences in the scans acquired in both the inclined and upright positions.

The increase in thickness and presence of fascial signal abnormalities are a highly sensitive parameter in that they are indicative of a pathological process. However, in our experience, they are nonspecific, as they were present both in patients with plantar fasciitis and in those with a partial tear $-4 / 15$ cases $(27 \%)$ in our study.

The partial tear in patients with plantar fasciitis was only demonstrated in images obtained in the upright position. There are no published studies evaluating the role of MR scans acquired during weight bearing in healthy individuals or patients with plantar fasciitis. Therefore, there are no reference standards to support the hypothesis that the areas of greater signal hyperintensity identified in plantar fasciitis during weight bearing are latent partial tears rendered visible by tension of the plantar fascia. We believe that evaluation in the weight-bearing position is important in terms of treatment approach, as it may be able to differentiate a partial tear from a simple plantar fasciitis and therefore change the type of treatment.

There are a number of limitations to our study, including: (1) the absence of a reference standard, which could be constituted by the intraoperative findings, the only incontrovertible evidence; and (2) the limited number of cases with a clinical diagnosis of plantar fasciitis and consequently the limited number of patients with assumed evidence of a fascial tear (only four cases), which only allow for the formulation of a hypothesis and not an affirmation supported by statistical evidence. In consideration of these limitations, we believe that further studies conducted on larger patient populations and with objective validation can confirm our hypothesis.

\section{Conclusions}

MR imaging of the plantar fascia during weight bearing with a dedicated MR system may be regarded as a reliable technique in evaluating anatomical-structural damage to the plantar fascia, as it demonstrates partial tears of the plantar fascia that could be overlooked in the supine position. riscontrato nel $40 \%$ dei casi (2/5), era di dimensioni limitate (diametro massimo $4 \mathrm{~mm}$ ) e verosimilmente dovuto ad alterazioni microtraumatiche da sovraccarico.

Il reperto accessorio sperone calcaneare è stato rilevato nel 46,67\% dei casi con fascite plantare, ma come evidenziato da altri autori la correlazione è casuale e non riveste alcuna rilevanza [1, 3, 9-11, 13]. I reperti associati e quelli accessori sono stati rilevati in egual misura senza significative differenze sia nelle acquisizioni in clinostatismo che in quelle sotto carico.

L'aumento dello spessore e la presenza di alterazioni del segnale della fascia risultano un parametro altamente sensibile in quanto indice di patologia, ma nella nostra esperienza aspecifico, poiché presente sia in corso di fascite plantare che di lesione parziale, come evidenziato nel nostro studio in $4 / 15$ casi $(27 \%)$.

La lesione parziale nel contesto dell'alterazione fascite plantare è stata dimostrata solo nelle immagini ottenute in ortostatismo. In letteratura non sono stati effettuati studi che valutino il ruolo delle acquisizioni sotto carico in RM della fascia plantare né in soggetti sani né con fascite plantare. Pertanto, non esistono degli standard di riferimento che supportino l'ipotesi che le aree di maggiore iperintensità di segnale rilevate nel contesto della fascite plantare sotto carico siano lesioni parziali slatentizzate dalla tensione della fascia plantare. Riteniamo che l'applicazione della valutazione in ortostatismo sia importante, in termini di approccio terapeutico, in quanto potrebbe, in alcuni casi, differenziare una lesione parziale da una semplice fascite plantare e cambiare il tipo di trattamento.

Tra le limitazioni del nostro studio riconosciamo: 1) l'assenza di un reference standard, quale può essere quella costituita dall'obiettività in sede intra-operatoria, unica evidenza incontrovertibile; 2) la limitata popolazione dei casi con diagnosi clinica di fascite plantare studiata e di conseguenza del numero di pazienti con supposta evidenza di rottura della fascia (solo 4 casi), che consentono solo la formulazione di un'ipotesi e non un'affermazione supportata da un'evidenza statistica. In considerazione delle limitazioni esposte riteniamo che ulteriori studi di maggiore dimensione campionaria e con verifica obiettiva possano dare conferma alla nostra ipotesi.

\section{Conclusioni}

L'imaging RM della fascia plantare sotto carico fisiologico mediante macchina RM dedicata potrebbe considerarsi una tecnica affidabile nella valutazione del danno anatomicostrutturale della fascia plantare permettendo di dimostrare rotture parziali della fascia plantare che possono rimanere misconosciute in clinostatismo. 
Conflict of interest statement The authors declare that they have no conflict of interest to the publication of this article.

\section{References/Bibliografia}

1. Grasel RP, Schweitzer ME, Kovalovich AM et al (1999) MR imaging of plantar fasciitis: edema, tears, and occult marrow abnormalities correlated with outcome. AJR Am J Roentgenol 173:699-701

2. Theodorou DJ, Theodorou SJ, Kakitsubata Y et al (2000) Plantar fasciitis and fascial rupture: MR imaging findings in 26 patients supplemented with anatomic data in cadavers. RadioGraphics 20:S181-S197

3. Theodorou DJ, Theodorou $\mathrm{Sj}$, Kakitsubata Y et al (2001) Disorders of the plantar aponeurosis: a spectrum of MR imaging findings. AJR Am J Roentgenol176:97-104
4. Buckup K (2004) Clinical tests for musculoskeletal system. Thieme, New York

5. Sorrentino F, Iovane A, Vetro A et al (2008) Role of high-resolution ultrasound in guiding treatment of idiopathic plantar fasciitis with minimally invasive techniques. Radiol Med 113:486-495

6. Tsai WC, Chiu MF, Wang CL et al (2000) Ultrasound evaluation of plantar fasciitis. Scand J Rheumatol 29:255-259

7. Sabir N, Demirlenk S, Yagci B et al (2005) Clinical utility of sonography in diagnosing plantar fasciitis. J

Ultrasound Med 24:1041-1048

8. Theodorou DJ, Theodorou SJ, Resnick D (2002) MR imaging of abnormalities of the plantar fascia. Semin Musculoskelet Radiol 6:105-118
9. Roger B, Greiner PH (1997) MRI of plantar fasciitis. Eur Radiol 7:1430-1435

10. Berkowitz JF, Kier R, Rudicel S (1991) Plantar fasciitis: MR imaging. Radiology 179:665-667

11. Narvaez JA, Narvaez J, Ortega R et al (2000) Painful heel: MR imaging findings. RadioGraphics 20:333-352

12. Wearing SC, Smeathers JE, Urry SR et al (2006) The pathomechanics of plantar fasciitis. Sports Med 36:585-611

13. Yu JS (2000) Pathologic and postoperative conditions of the plantar fascia: review of MR imaging appearance. Skeletal Radiol 29:491-501

14. Saxena A, Fullem B (2004) Plantar fascia ruptures in athletes. Am J Sports Med 32:662-665 